UDC 665.939.4:633.111

\title{
CHARACTERIZATION OF AMINO ACID CONTENT OF GRAIN OF NEW WHEAT VARIETIES AND LINES
}

\author{
H. M. Hospodarenko, V. P. Karpenko, V. V. Liubych, V. V. Novikov \\ Uman National University of Horticulture \\ 1, Instytutska Str, Uman, Cherkasy Region, 20300, Ukraine \\ E-mail: Hospodarenko@gmail.com,v-biology@ukr.net,LyubichV@gmail.com,1990vovanovikov1990@gmail.com
}

Received September 19, 2018 / Received October 19, 2018 / Accepted November 21, 2018

\begin{abstract}
Aim. To determine the formation of bound amino acids in grain of new wheat varieties and its biological value. Methods. Field, physical-chemical, computational, analysis. Results. The differences in amino acid composition of new varieties and lines of wheat were analyzed. It was established that the highest content of essential amino acids was in the grain of the Kulundynka variety $(5.18 \%)$ or 2.5 times higher compared to the standard $(2.99 \%)$. Their content in the grain of soft wheat, obtained by the hybridization of Triticum aestivum L./Triticum spelta L., was 1.4-1.5 times higher compared to the control. The grain of the soft variety Kulundynka had the highest biological value as the score of essential amino acids was not deficient and the remaining varieties were deficient in 2-5 amino acids. Only methionine was deficient in the grain of soft wheat lines (AAS = 64$74 \%$ ). Conclusions. The content of amino acids in soft wheat grain depends considerably on weather conditions, selective-genetic origin of the variety and the line. Glutamic acid, proline, and leucine were found to be most abundant. Out of nine samples of soft wheat tested, only the seed of the Kulundynka variety had a nondeficient amino acid score (91-298 \%), and in the Pannonikus variety methionine was limited (49\%). The best balanced content of amino acids is present in the grain of non-spelt lines, obtained by hybridization of Triticum aestivum L. and Triticum spelta L., namely P 7 and LPP 1314. The grain of these lines has a non-deficient amino acid score, more methionine (AAS $=64-74 \%$ ), and supplies human daily requirement in the best way. The grain has a high index of complex estimation and metabolization coefficient for essential amino acids.
\end{abstract}

Keywords: amino acids, grain, soft wheat, variety.

DOI: https://doi.org/10.15407/agrisp5.03.012

\section{INTRODUCTION}

According to the data of FAO experts, the developed countries with about $20 \%$ of the world population supply about $50 \%$ of the world production of wheat grain $[1,2]$.

It is possible to solve the problem of producing vegetative protein, valuable for bread baking and confectionary production, using grain of minor wheat varieties or introgressive lines due to higher content of protein and better balance in terms of essential amino acids $[3,4]$. In addition, there are a great number of newly hybridized introgressive varieties and lines of wheat, the amino acid composition and biological value of which has not been studied in fine detail $[5,6]$.

(C) H. M. HOSPODARENKO, V. P. KARPENKO, V. V. LIUBYCH, V. V. NOVIKOV, 2018
One of the most important parameters of grain quality is the quantitative content of essential amino acids [7]. The information on the nutritional content of foods brings the knowledge to bear on the goals of food analysis and food science, may contribute to the establishment of policies on food production and storage, the evaluation of the nutritional status, the formulation of therapeutic diets and investigations into the relationships between diet, health and disease [8].

The essential amino acid parameter is not stable, and may change depending on wheat variety, weather conditions and agrotechnology $[9,10]$. Therefore, the determination of amino acid composition of seed protein and its biological value in the grain of new varieties and lines becomes eminent.

AGRICULTURAL SCIENCE AND PRACTICE Vol. 5 No. 32018 


\section{CHARACTERIZATION OF AMINOACID CONTENT OF GRAIN OF DIFFERENT WHEAT VARIETIES}

\section{MATERIALS AND METHODS}

The experimental part of the work was conducted in the Laboratory of estimating the quality of grain and grain products at the Uman National University of Horticulture. The grain of soft winter wheat of the following varieties was used: Podolianka, Kokhana, Chornobrova with violet kernel, developed in Ukraine, and the varieties produced in other European countries, North America and Africa - Pannonikus (Austria), Emerino (Cyprus), white grain Kulundynka (Russia), Ac Meckinon (Canada) as well as the lines obtained by hybridization of Triticum aestivum and Triticum spelta - LPP 1314, P 7 (Ukraine). All varieties and lines were grown in the conditions of the Right-Bank Forest-Steppe of Ukraine in 2013-2015. The area-specific variety of soft winter wheat (national standard) Podolianka (st) was used as standard.

The experimental plot is located at Mankivsky natural farmland of the Medium Dnieper-Bug District in the Right-Bank Forest-Steppe with the Greenwich geographical coordinates of $48^{\circ} 46 ' 56,47^{\prime \prime}$ north latitude and $30^{\circ} 14 ' 48,51^{\prime \prime}$ east longitude. The altitude is $245 \mathrm{~m}$. The soil of the experimental field is podzolic chernozem. The thickness of the soil profile, including $\mathrm{P}(\mathrm{h}) \mathrm{k}$ horizon, is 140 $160 \mathrm{~cm}$. The structure of soil within the profile is moderately dense, the granulometric composition is even. The degree of base saturation is $87-97 \%$ with the medium acid reaction of the soil solution. The potential acidity fluctuates from 1.8 to $4.2 \mathrm{cmol} / \mathrm{kg}$ of soil. The maximal capacity of absorbing cations in the upper horizon is $29-32 \mathrm{cmol} / \mathrm{kg}$ of soil.

In 2012 and 2013, the weather conditions were characterized by a smaller amount of precipitation, with 178 and $209 \mathrm{~mm}$ of precipitation in April-July respectively, or $15-36 \%$ less compared to the mean perennial index $(277 \mathrm{~mm})$. There was a sufficient amount of precipitation in 2014 and 2015. In AprilJuly, there were 374, 292 and $271 \mathrm{~mm}$ of precipitation respectively, but their distribution was different. In 2013, there were only $13.3 \mathrm{~mm}$, in $2015-45.8$, and in $2014-140.8 \mathrm{~mm}$ of precipitation in the phase of stem elongation. Air temperature also had its impact on the growth and development of wheat varieties and lines. For instance, during the period of intense growth of the stem (stem elongation - earing) in 2013 it was unfavorable compared to the optimal temperature (9$16{ }^{\circ} \mathrm{C}$ ), amounting to $18-21{ }^{\circ} \mathrm{C}$. During the remaining years of the studies, the air temperature was optimal.
During the period of grain ripening, the air temperature was below the optimal indices $\left(22-25^{\circ} \mathrm{C}\right)$, in addition, there were $65.6-143.6 \mathrm{~mm}$ of precipitation.

The predecessor crop was oat (Avena sativa L.), cultivated for green fodder. Wheat was grown without any fertilizers or protectors.

The content of bound amino acids was determined by the method of ion-exchange liquid chromatography with the analyzer for amino acids T-339 (Mikrotechna, Czech Republic, Prague).

The Amino Acid Score (AAS) was defined by the following formula [8] according to $\mathrm{FAO} / \mathrm{WHO}$ :

$$
A=\frac{A c}{O} \times 100
$$

where A - amino acid score, \%; Ac - actual content of amino acid, $\mathrm{mg} / \mathrm{g}$ of grain; $\mathrm{O}$ - optimal content of amino acid, $\mathrm{mg} / \mathrm{g}$ of grain.

The integral score was defined by the following formula:

$$
A=\frac{A c}{D} \times 100,
$$

where A - amino acid score, \%; Ac - actual content of amino acid, g/100 g of grain; D - daily requirement of this component by the organism of an adult, $g$.

The metabolization efficiency coefficient (MEC) of

$$
M E C=\frac{\sum E A}{\sum N A},
$$

essential amino acids was determined by the formula: where $\Sigma$ EA - content of essential amino acids, \%; $\Sigma \mathrm{NA}$ - content of non-essential amino acids, $\%$.

The index of complex estimation (ICE) was determined by the formula:

$$
I C E=\sqrt[n]{\frac{A c_{1}}{O_{1}} \times \frac{A c_{2}}{A c_{2}} \times \cdots \times \frac{A c_{n}}{O_{n}} \times \frac{P_{1}}{A c_{1}} \times \frac{P_{2}}{A c_{2}} \times \cdots \times \frac{P_{n}}{A c_{n}}}
$$

where Ac - actual value of the index; $\mathrm{O}$ - optimal value of the index; $\mathrm{P}$ - permissible value of the index; $\mathrm{Ac} / \mathrm{O}$ - ratio, used for indices, the actual value of which should exceed the optimal one; P/Ac - ratio, used for indices, the actual value of which should be lower than the permissible level; $n$ - number of indices, used in the model.

The statistical processing of the data was conducted in Microsoft Excel 2010 and STATISTICA 10. The interpretation of the impact level by the coefficient (thumb rule - Cohen): 0.02-0.13 - weak, 0.13-0.26medium, $\geq 0.26-$ high. 


\section{HOSPODARENKO et al.}

The dispersion analysis was used to confirm or refute "null hypothesis". The method envisaged the value of coefficient " $p$ ", which demonstrated the probability of the respective hypothesis. In case of $p<0.05$, the null hypothesis was refuted and the impact of the factor was reliable [11, 12].

\section{RESULTS AND DISCUSSION}

The sum of amino acids in the grain of soft wheat varieties varied from $10.55 \%$ in the variety Ac Mackinnon to $17.47 \%$ in the variety Kulundynka (Table 1).

In the grain of soft wheat lines, obtained by hybridization of Triticum aestivum L./Triticum spelta L., the sum of amino acids varied from 15.03 to $16.17 \%$, which was in general considerably higher as compared to the standard variety Podolianka $(11.06 \%$, at $5 \%$ Least Significant Difference, $5 \% L S D=0.68$ ).
The content of essential amino acids was considerably higher compared to the standard $(L S D=0.21)$. The highest content of essential amino acids was in the grain of variety Kulundynka (5.18 \%). The standard had $2.99 \%$ essential amino acids.

We also found that the content of amino acids in wheat grain was strongly correlated with the variety and weather conditions (Fig.). The impact degree of the variety was the highest for essential amino acids 0.71 and 0.93 - for non-essential acids. The degree of impact of weather conditions was 0.62 .

The grain of other wheat lines was also characterized by high content of this group of amino acids. The content of essential amino acids in wheat lines, obtained by hybridization of Triticum aestivum L./Triticum spelta L., was from 4.17 to $4.51 \%$ or $1.4-1.5$ times higher compared to the control.

Table 1. The content of bound amino acids in the grain of some varieties and lines of wheat, mean for the period of 20132015 , in $\%$

\begin{tabular}{|c|c|c|c|c|c|c|c|c|c|c|}
\hline \multirow{2}{*}{$\begin{array}{l}\text { Amino } \\
\text { acid }\end{array}$} & \multicolumn{10}{|c|}{ Variety, line } \\
\hline & $\begin{array}{c}\text { Podo- } \\
\text { lianka (st) }\end{array}$ & Kokhana & Emerino & $\begin{array}{l}\text { Panno- } \\
\text { nikus }\end{array}$ & $\begin{array}{c}\text { Ac } \\
\text { Mackinnon }\end{array}$ & $\begin{array}{l}\text { Kulun- } \\
\text { dynka }\end{array}$ & $\begin{array}{c}\text { Chorno- } \\
\text { brova }\end{array}$ & LPP 1314 & P7 & $L S D_{05}$ \\
\hline Val & 0.48 & 0.52 & 0.52 & 0.47 & 0.54 & 0.66 & 0.53 & 0.68 & 0.63 & 0.03 \\
\hline Ile & 0.38 & 0.42 & 0.54 & 0.49 & 0.41 & 0.75 & 0.43 & 0.65 & 0.45 & 0.03 \\
\hline Leu & 0.59 & 0.69 & 0.68 & 0.70 & 0.76 & 0.98 & 0.66 & 0.85 & 0.77 & 0.04 \\
\hline Lys & 0.37 & 0.41 & 0.40 & 0.56 & 0.43 & 0.71 & 0.47 & 0.54 & 0.61 & 0.03 \\
\hline Meth & 0.06 & 0.07 & 0.07 & 0.10 & 0.08 & 0.15 & 0.07 & 0.08 & 0.09 & 0.01 \\
\hline Thre & 0.33 & 0.37 & 0.34 & 0.54 & 0.37 & 0.74 & 0.36 & 0.47 & 0.58 & 0.02 \\
\hline Try & 0.27 & 0.33 & 0.32 & 0.41 & 0.28 & 0.42 & 0.40 & 0.54 & 0.45 & 0.02 \\
\hline Phen & 0.50 & 0.58 & 0.52 & 0.56 & 0.48 & 0.69 & 0.42 & 0.66 & 0.59 & 0.03 \\
\hline$\Sigma_{\mathrm{e}}$ & 2.99 & 3.39 & 3.39 & 3.85 & 3.36 & 5.18 & 3.34 & 4.51 & 4.17 & 0.21 \\
\hline Ala & 0.43 & 0.61 & 0.46 & 0.78 & 0.49 & 0.93 & 0.42 & 0.80 & 0.71 & 0.03 \\
\hline Arg & 0.49 & 0.70 & 0.51 & 0.87 & 0.61 & 1.05 & 0.55 & 0.80 & 0.87 & 0.04 \\
\hline Asp & 0.53 & 0.71 & 0.71 & 0.99 & 0.70 & 1.13 & 0.91 & 0.92 & 1.22 & 0.04 \\
\hline His & 0.50 & 0.52 & 0.48 & 0.70 & 0.43 & 0.79 & 0.44 & 0.82 & 0.76 & 0.03 \\
\hline Gly & 0.48 & 0.54 & 0.51 & 0.74 & 0.49 & 0.81 & 0.46 & 0.84 & 0.83 & 0.03 \\
\hline Glu & 3.43 & 3.97 & 3.27 & 3.52 & 2.55 & 3.86 & 3.78 & 4.30 & 3.88 & 0.16 \\
\hline Pro & 1.17 & 1.07 & 1.02 & 1.14 & 0.94 & 1.66 & 0.95 & 1.31 & 0.99 & 0.06 \\
\hline Ser & 0.65 & 0.66 & 0.53 & 0.93 & 0.56 & 1.10 & 0.49 & 0.92 & 0.88 & 0.04 \\
\hline Thir & 0.33 & 0.45 & 0.39 & 0.44 & 0.30 & 0.80 & 0.35 & 0.78 & 0.50 & 0.02 \\
\hline Cys & 0.06 & 0.12 & 0.09 & 0.11 & 0.10 & 0.23 & 0.11 & 0.19 & 0.22 & 0.01 \\
\hline$\Sigma_{\mathrm{ne}}$ & 8.07 & 9.36 & 7.96 & 10.18 & 7.19 & 12.29 & 8.47 & 11.65 & 10.87 & 0.47 \\
\hline$\Sigma_{\mathrm{s}}$ & 11.06 & 12.75 & 11.35 & 14.03 & 10.55 & 17.47 & 11.81 & 16.17 & 15.03 & 0.68 \\
\hline
\end{tabular}



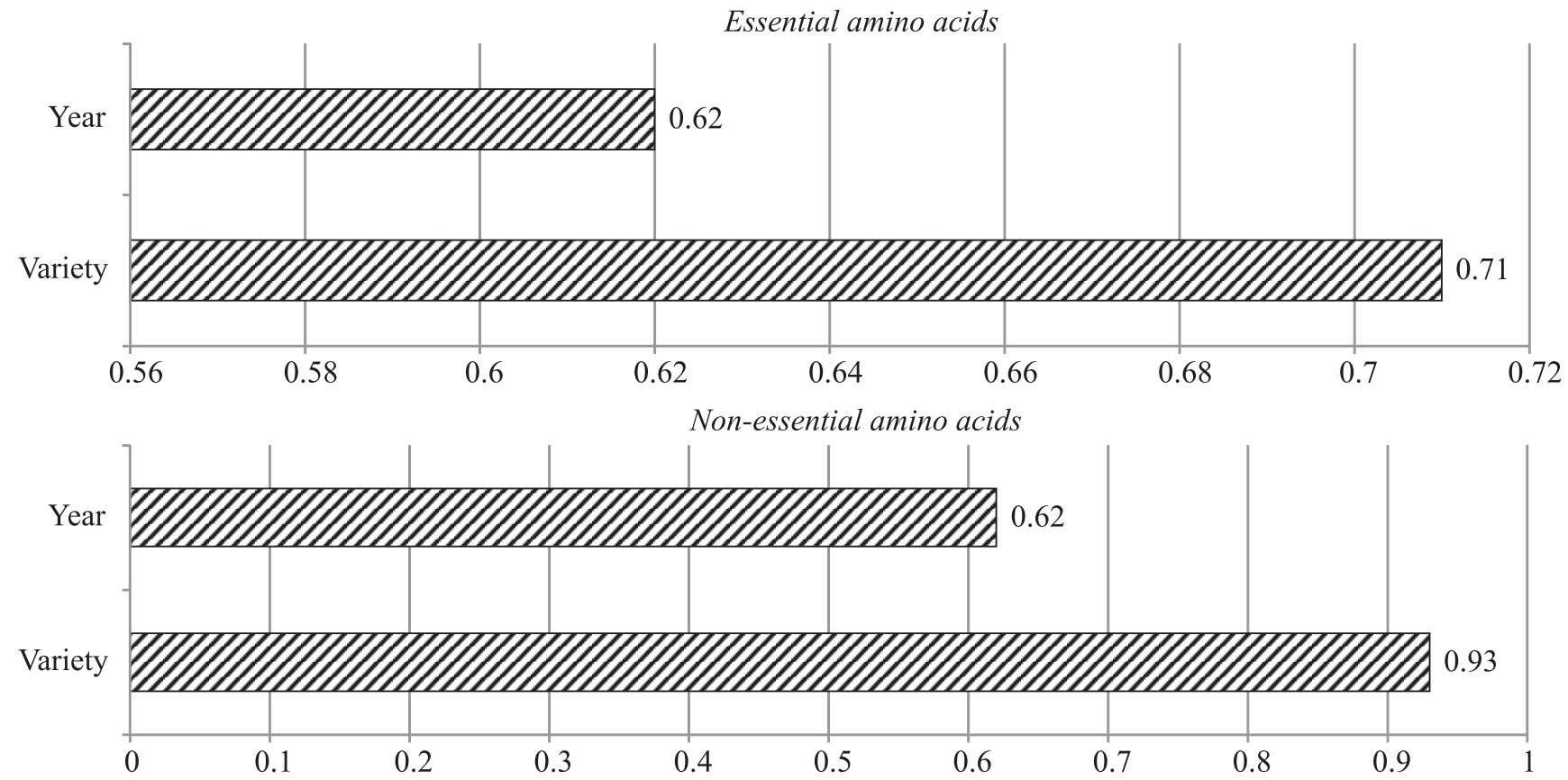

Fig. 1. The degree of impact of the factors under investigation on the content of amino acids

The main component of the amino acid composition of wheat grain is glutamic acid, the content varied from 2.55 to $4.30 \%$ depending on the variety and line. The content of leucine and proline was higher as compared to other amino acids - from $0.59 \%$ in Podolianka variety grain to $0.98 \%$ in Kulundynka variety grain. The lowest indices were registered for the content of cystine, which varied from 0.06 to $0.23 \%$.

It is known that the content of protein or sum of amino acids does not correspond to high biological value of grain $[13,14]$. In addition, the content of amino acids does not carry any information about meeting human organism requirements. Therefore, the value of amino acid score is calculated [14]. It is known that lysine and methionine are limiting amino acids in wheat protein in most varieties and lines, the amino acid score of which varied in our hands from 29 to $91 \%$ (Table 2).

It was determined that at the accuracy of determining the content of amino acids in grain of about $5 \%$, the score of $95 \%$ is considered to be non-deficient [15].

Thus, the protein of Kulundynka variety grain is the most balanced, as the score of essential amino acids is non-deficient, and the remaining varieties and lines are deficient in 2-5 more amino acids in addition to lysine

Table 2. The amino acid score of grain of varieties and lines of different wheat species (2013-2015), \%

\begin{tabular}{l|c|c|c|c|c|c|c|c}
\hline \multirow{2}{*}{ Variety, line } & \multicolumn{7}{c}{ Amino acid } \\
\cline { 2 - 8 } & Meth + cys & Lys & Thre & Val & Ile & Leu & Try & Phen + thir \\
\cline { 2 - 9 } & $29 \pm 7^{\mathrm{c}}$ & $76 \pm 5^{\mathrm{a}}$ & $76 \pm 15^{\mathrm{c}}$ & $88 \pm 15^{\mathrm{b}}$ & $88 \pm 12^{\mathrm{b}}$ & $107 \pm 2^{\mathrm{a}}$ & $144 \pm 123^{\mathrm{c}}$ & $162 \pm 6 \mathrm{a}$ \\
Podolianka (st) & $44 \pm 5^{\mathrm{b}}$ & $84 \pm 8^{\mathrm{b}}$ & $85 \pm 18^{\mathrm{c}}$ & $96 \pm 11^{\mathrm{b}}$ & $95 \pm 15^{\mathrm{b}}$ & $128 \pm 12^{\mathrm{b}}$ & $165 \pm 128^{\mathrm{c}}$ & $206 \pm 35^{\mathrm{b}}$ \\
Kokhana & $34 \pm 11^{\mathrm{c}}$ & $73 \pm 9^{\mathrm{b}}$ & $63 \pm 21^{\mathrm{c}}$ & $81 \pm 29^{\mathrm{c}}$ & $97 \pm 37^{\mathrm{c}}$ & $103 \pm 35^{\mathrm{c}}$ & $138 \pm 91^{\mathrm{c}}$ & $170 \pm 14 \mathrm{a}$ \\
Emerino & $49 \pm 17^{\mathrm{c}}$ & $112 \pm 7^{\mathrm{a}}$ & $122 \pm 30^{\mathrm{c}}$ & $85 \pm 26^{\mathrm{c}}$ & $113 \pm 35^{\mathrm{c}}$ & $121 \pm 19^{\mathrm{b}}$ & $212 \pm 174^{\mathrm{c}}$ & $189 \pm 28 \mathrm{~b}$ \\
Pannonikus & $44 \pm 8^{\mathrm{b}}$ & $90 \pm 16^{\mathrm{b}}$ & $85 \pm 7^{\mathrm{a}}$ & $98 \pm 9^{\mathrm{a}}$ & $93 \pm 16 \mathrm{~b}$ & $149 \pm 33^{\mathrm{c}}$ & $130 \pm 90^{\mathrm{c}}$ & $159 \pm 32^{\mathrm{c}}$ \\
Ac Mackinnon & $91 \pm 12^{\mathrm{b}}$ & $144 \pm 15^{\mathrm{b}}$ & $169 \pm 19^{\mathrm{b}}$ & $120 \pm 13^{\mathrm{b}}$ & $172 \pm 8^{\mathrm{a}}$ & $187 \pm 28^{\mathrm{b}}$ & $210 \pm 164^{\mathrm{c}}$ & $298 \pm 30^{\mathrm{b}}$ \\
Kulundynka & $43 \pm 10^{\mathrm{c}}$ & $97 \pm 16^{\mathrm{b}}$ & $82 \pm 6^{\mathrm{a}}$ & $96 \pm 10^{\mathrm{b}}$ & $97 \pm 15^{\mathrm{b}}$ & $126 \pm 28^{\mathrm{c}}$ & $185 \pm 126^{\mathrm{c}}$ & $157 \pm 28^{\mathrm{b}}$ \\
Chornobrova & $64 \pm 10^{\mathrm{b}}$ & $112 \pm 16^{\mathrm{b}}$ & $106 \pm 9^{\mathrm{a}}$ & $125 \pm 9^{\mathrm{a}}$ & $148 \pm 10^{\mathrm{a}}$ & $165 \pm 32^{\mathrm{c}}$ & $240 \pm 150^{\mathrm{c}}$ & $291 \pm 52^{\mathrm{c}}$ \\
LPP 1314 & $74 \pm 17^{\mathrm{c}}$ & $120 \pm 33^{\mathrm{c}}$ & $133 \pm 24^{\mathrm{b}}$ & $114 \pm 30^{\mathrm{c}}$ & $102 \pm 26^{\mathrm{c}}$ & $141 \pm 25^{\mathrm{c}}$ & $237 \pm 200^{\mathrm{c}}$ & $208 \pm 27^{\mathrm{b}}$ \\
P 7 & & & & & & &
\end{tabular}




\section{HOSPODARENKO et al.}

Table 3. The mean amino acid content (\%) of essential amino acids per $100 \mathrm{~g}$ of grain of some varieties and lines of wheat determined over the period 2013-2015

\begin{tabular}{|c|c|c|c|c|c|c|c|c|c|}
\hline \multirow{2}{*}{$\begin{array}{l}\text { Amino } \\
\text { acid }\end{array}$} & \multicolumn{9}{|c|}{ Variety, line } \\
\hline & $\begin{array}{c}\text { Podo- } \\
\text { lianka (st) }\end{array}$ & Kokhana & Emerino & $\begin{array}{l}\text { Panno- } \\
\text { nikus }\end{array}$ & $\begin{array}{c}\text { Ac } \\
\text { Mackinnon }\end{array}$ & $\begin{array}{l}\text { Kulun- } \\
\text { dynka }\end{array}$ & $\begin{array}{c}\text { Chorno- } \\
\text { brova }\end{array}$ & LPP 1314 & P 7 \\
\hline Val & $19 \pm 4^{b}$ & $21 \pm 3^{b}$ & $21 \pm 3^{b}$ & $19 \pm 6^{c}$ & $22 \pm 2^{\mathrm{a}}$ & $26 \pm 3^{b}$ & $21 \pm 2^{b}$ & $28 \pm 3^{a}$ & $25 \pm 7^{c}$ \\
\hline Ile & $20 \pm 3^{b}$ & $21 \pm 4^{\mathrm{b}}$ & $27 \pm 2^{\mathrm{a}}$ & $25 \pm 8^{c}$ & $21 \pm 4^{\mathrm{b}}$ & $38 \pm 2^{\mathrm{a}}$ & $22 \pm 4^{b}$ & $33 \pm 2^{\mathrm{a}}$ & $23 \pm 6^{c}$ \\
\hline Leu & $13 \pm 4^{c}$ & $15 \pm 3^{b}$ & $15 \pm 3^{b}$ & $15 \pm 7^{\mathrm{c}}$ & $17 \pm 2^{\mathrm{a}}$ & $22 \pm 2^{\mathrm{a}}$ & $14 \pm 2^{\mathrm{b}}$ & $19 \pm 2^{b}$ & $17 \pm 5^{\mathrm{c}}$ \\
\hline Lys & $10 \pm 2^{\mathrm{b}}$ & $10 \pm 2^{b}$ & $10 \pm 1^{\mathrm{a}}$ & $14 \pm 3^{c}$ & $11 \pm 1^{\mathrm{a}}$ & $18 \pm 3^{b}$ & $12 \pm 2^{\mathrm{b}}$ & $13 \pm 1^{\mathrm{a}}$ & $15 \pm 5^{c}$ \\
\hline Meth & $3 \pm 1^{c}$ & $4 \pm 1^{b}$ & $4 \pm 1^{c}$ & $6 \pm 1^{b}$ & $5 \pm 2^{c}$ & $9 \pm 2^{c}$ & $4 \pm 1^{b}$ & $5 \pm 1^{b}$ & $5 \pm 1^{b}$ \\
\hline Thre & $14 \pm 3^{c}$ & $16 \pm 4^{c}$ & $15 \pm 3^{c}$ & $23 \pm 6^{c}$ & $16 \pm 2^{\mathrm{a}}$ & $32 \pm 4^{b}$ & $15 \pm 2^{\mathrm{a}}$ & $20 \pm 2^{\mathrm{a}}$ & $25 \pm 5^{b}$ \\
\hline Try & $35 \pm 10^{c}$ & $42 \pm 5^{b}$ & $40 \pm 2^{a}$ & $52 \pm 9^{c}$ & $35 \pm 5^{b}$ & $53 \pm 15^{\mathrm{c}}$ & $51 \pm 3^{a}$ & $68 \pm 4^{\mathrm{a}}$ & $57 \pm 13^{c}$ \\
\hline Phen & $12 \pm 4^{c}$ & $13 \pm 2^{\mathrm{b}}$ & $12 \pm 2^{\mathrm{b}}$ & $13 \pm 4^{c}$ & $11 \pm 2^{b}$ & $16 \pm 4^{c}$ & $10 \pm 1^{\mathrm{a}}$ & $15 \pm 2^{b}$ & $14 \pm 5^{c}$ \\
\hline Ala & $7 \pm 1^{\mathrm{a}}$ & $9 \pm 2^{b}$ & $7 \pm 1^{\mathrm{a}}$ & $12 \pm 3^{c}$ & $8 \pm 1^{a}$ & $14 \pm 2^{b}$ & $7 \pm 1^{\mathrm{a}}$ & $13 \pm 1^{\mathrm{a}}$ & $11 \pm 2^{b}$ \\
\hline Arg & $8 \pm 2^{b}$ & $12 \pm 3^{c}$ & $9 \pm 2^{b}$ & $14 \pm 1^{\mathrm{a}}$ & $10 \pm 1^{\mathrm{a}}$ & $18 \pm 2^{\mathrm{a}}$ & $9 \pm 1^{\mathrm{a}}$ & $13 \pm 1^{\mathrm{a}}$ & $15 \pm 3^{c}$ \\
\hline Asp & $5 \pm 1^{c}$ & $6 \pm 1^{b}$ & $6 \pm 1^{b}$ & $9 \pm 2^{b}$ & $6 \pm 1^{a}$ & $10 \pm 2^{b}$ & $8 \pm 1^{a}$ & $8 \pm 1^{\mathrm{a}}$ & $10 \pm 2^{\mathrm{b}}$ \\
\hline His & $24 \pm 5^{c}$ & $25 \pm 1^{\mathrm{a}}$ & $23 \pm 2^{\mathrm{a}}$ & $33 \pm 4^{b}$ & $21 \pm 1^{\mathrm{a}}$ & $38 \pm 2^{\mathrm{a}}$ & $21 \pm 2^{\mathrm{a}}$ & $40 \pm 2^{\mathrm{a}}$ & $37 \pm 7^{\mathrm{b}}$ \\
\hline Gly & $14 \pm 4^{c}$ & $16 \pm 1^{\mathrm{a}}$ & $15 \pm 4^{c}$ & $21 \pm 2^{\mathrm{a}}$ & $14 \pm 1^{\mathrm{a}}$ & $24 \pm 5^{c}$ & $14 \pm 2^{\mathrm{a}}$ & $24 \pm 1^{\mathrm{a}}$ & $24 \pm 3^{b}$ \\
\hline Glu & $26 \pm 2^{\mathrm{a}}$ & $30 \pm 1^{\mathrm{a}}$ & $24 \pm 2^{\mathrm{a}}$ & $26 \pm 2^{\mathrm{a}}$ & $19 \pm 3^{b}$ & $29 \pm 3^{a}$ & $28 \pm 1^{\mathrm{a}}$ & $32 \pm 1^{\mathrm{a}}$ & $29 \pm 1^{\mathrm{a}}$ \\
\hline Pro & $26 \pm 2^{\mathrm{a}}$ & $24 \pm 4^{b}$ & $23 \pm 4^{b}$ & $26 \pm 6^{c}$ & $21 \pm 4^{b}$ & $37 \pm 2^{\mathrm{a}}$ & $21 \pm 4^{b}$ & $30 \pm 2^{\mathrm{a}}$ & $22 \pm 4^{b}$ \\
\hline Ser & $8 \pm 1^{b}$ & $8 \pm 2^{b}$ & $6 \pm 2^{c}$ & $12 \pm 1^{\mathrm{a}}$ & $7 \pm 1^{\mathrm{b}}$ & $13 \pm 1^{\mathrm{a}}$ & $6 \pm 1^{b}$ & $12 \pm 1^{\mathrm{a}}$ & $11 \pm 2^{\mathrm{b}}$ \\
\hline Thir & $8 \pm 2^{b}$ & $11 \pm 2^{b}$ & $9 \pm 2^{b}$ & $10 \pm 4^{c}$ & $7 \pm 1^{a}$ & $19 \pm 1^{\mathrm{a}}$ & $9 \pm 2^{b}$ & $18 \pm 2^{\mathrm{a}}$ & $12 \pm 5^{c}$ \\
\hline Cys & $4 \pm 1^{b}$ & $7 \pm 2^{b}$ & $5 \pm 2^{c}$ & $6 \pm 3^{c}$ & $6 \pm 2^{c}$ & $13 \pm 1^{\mathrm{a}}$ & $6 \pm 2^{c}$ & $11 \pm 3^{c}$ & $13 \pm 4^{c}$ \\
\hline
\end{tabular}

Note. $\mathrm{a}-$ insignificant variation $(\mathrm{V}=0-10 \%) ; \mathrm{b}-$ medium variation $(\mathrm{V}=10-20 \%)$; $\mathrm{c}$ - significant variation $(\mathrm{V}=\geq 20 \%)$.

and methionine. The amino acid score of tryptophane and phenylalanine was non-deficient in grain of all the varieties and lines of wheat.

In the studies of Graciela Caire-Juvera, Francisco A. et al. [8] the amino acid score of lysine for grain products of wheat was $15-54 \%$, for methionine - 41$47 \%$. However, this index was estimated for children aged 1-2 y.o., whose requirement in amino acids is higher compared to adults, therefore, it is lower.

The calculations demonstrated that $100 \mathrm{~g}$ of grain of varieties and lines of wheat species meet the biological requirement of an adult in tryptophane the most (35$68 \%$ ) (Table 3). The lowest integral score of $100 \mathrm{~g}$ of grain meets the requirement in methionine - for 3-6\% depending on the varieties and lines of wheat, and for the rest of amino acids - for 4-40\%. The biological requirement was met in the best way by $100 \mathrm{~g}$ of grain of varieties Kulundynka (9-53 \%), P 7 and LPP 1314 lines - for 5-68 \% depending on the amino acid.
Table 4. The metabolization efficiency coefficient and the index of complex estimation of the content of essential ami-no acids in the grain of varieties and lines of wheat, 2013-2015

\begin{tabular}{l|c|c|}
\hline \multicolumn{1}{c|}{ Variety, line } & MEC & ICE \\
\hline Podolianka (st) & $0.38 \pm 0.06^{\mathrm{b}}$ & $0.83 \pm 0.16^{\mathrm{c}}$ \\
Kokhana & $0.36 \pm 0.04^{\mathrm{b}}$ & $0.99 \pm 0.13^{\mathrm{b}}$ \\
Emerino & $0.43 \pm 0.03^{\mathrm{a}}$ & $0.96 \pm 0.09^{\mathrm{a}}$ \\
Pannonikus & $0.38 \pm 0.07^{\mathrm{b}}$ & $1.12 \pm 0.33^{\mathrm{c}}$ \\
Ac Mackinnon & $0.47 \pm 0.04^{\mathrm{a}}$ & $0.95 \pm 0.02^{\mathrm{a}}$ \\
Kulundynka & $0.42 \pm 0.03^{\mathrm{a}}$ & $1.57 \pm 0.17^{\mathrm{b}}$ \\
Chornobrova & $0.40 \pm 0.04^{\mathrm{a}}$ & $0.98 \pm 0.11^{\mathrm{b}}$ \\
LPP 1314 & $0.39 \pm 0.03^{\mathrm{a}}$ & $1.37 \pm 0.12^{\mathrm{a}}$ \\
P 7 & $0.38 \pm 0.05^{\mathrm{b}}$ & $1.27 \pm 0.31^{\mathrm{c}}$ \\
\hline
\end{tabular}

Note. a - insignificant variation $(\mathrm{V}=0-10 \%)$; $\mathrm{b}-$ medium variation $(\mathrm{V}=10-20 \%) ; \mathrm{c}-$ significant variation $(\mathrm{V}=\geq 20 \%)$.

AGRICULTURAL SCIENCE AND PRACTICE Vol. 5 No. 32018 


\section{CHARACTERIZATION OF AMINOACID CONTENT OF GRAIN OF DIFFERENT WHEAT VARIETIES}

The highest metabolization coefficient of essential amino acids was in the grain of varieties Kulundynka (0.42), Emerino (0.43) and Ac Mackinnon (0.47) or $11-24 \%$ higher as compared to the control $(0.38)$ (Table 4). As for grain of other soft wheat varieties, this coefficient varied from 0.36 to 0.40 .

ICE index characterizes the levels of several indices compared to the optimal values. If ICE $=\leq 1$, the actual value of indices is below the optimal one, ICE $=1-$ actual values correspond to the optimal ones, ICE $=\geq$ $\geq 1$ - actual values exceed the optimal ones.

The highest index of complex estimation (ICE) of the content of essential amino acids was registered in the grain of varieties Pannonikus (1.12), Kulundynka (1.57) and P 7 (1.27), LPP 1314 (1.37) lines. The lowest index was in the grain of Podollianka variety -0.83 . ICE in other varieties was from 0.95 to 0.98 .

\section{CONCLUSIONS}

The content of amino acids in wheat grain depends the most on selective-genetic origin of the variety and the line. Out of nine samples of soft wheat, only the grain of Kulundynka variety had a non-deficient total amino acid score. In the variety Pannonikus, methionine $(\mathrm{AAS}=49 \%)$ and valine $(\mathrm{AAS}=81 \%)$ appeared to be limited as the content of amino acid was lower compared to the index of the ideal product.

The best-balanced content of amino acids is present in the grain of non-spelt lines P 7 and LPP 1314, obtained by hybridization of Triticum aestivum L./ Triticum spelta $\mathrm{L}$. The grain of these lines has a nondeficient amino acid score and supplies the human daily requirement in the best way. This grain has 1.1-1.3 times higher content of glutamic, 1.6-1.8 times higher content of arginine, 1.7 times - that of glycine, 1.3-1.4 times - leucine, and 1.3-1.4 times valine compared to the standard (Podolianka variety). The grain has a high index of complex estimation for essential amino acids.

It is recommended to use Kulundynka variety, lines P 7 and LPP 1314, in the breeding of wheat varieties, as they have a non-deficient score of essential amino acids in grain.

\section{Характеристика амінокислотного складу зерна нових сортів і ліній пшениці}

Г. М. Господаренко, В. П. Карпенко, В. В. Любич, В. В. Новіков

Уманський національний університет садівництва вул. Інститутська, 1, м. Умань,

\author{
Черкаська обл., 20300, Україна \\ e-mail: Hospodarenko@gmail.com, \\ v-biology@ukr.net, LyubichV@gmail.com, \\ 1990vovanovikov1990@gmail.com
}

Мета. Визначити формування зв'язаних амінокислот у зерні різних сортів пшениці та його біологічну цінність. Методи. Польовий, фізико-хімічний, розрахунковий, аналізування. Результати. Проаналізовано відмінності амінокислотного складу нових сортів і ліній пшениць. Встановлено, що найвищий вміст есенційних амінокислот був у зерні сорту Кулундинка (5,18 \%) або більше в 2,3 рази порівняно зі стандартом $(2,99 \%)$. У зерні ліній пшениці м'якої, отриманих гібридизацією Triticum aestivum L./Triticum spelta L., їх вміст в 1,4-1,5 рази більший порівняно з контролем. Зерно пшениці м'якої сорту Кулундинка має найвищу біологічну цінність, тому що скор есенційних амінокислот бездефіцитний, а решта сортів мають дефіцит 2-5 амінокислот. У зерні ліній пшениці м'якої лише метіонін був у дефіциті (амінокислотний скор 64-74\%). Висновки. Вміст амінокислот у зерні м'якої пшениці істотно залежить від погодних умов, селекційно-генетичного походження сорту та лінії. Глутамінова кислота, пролін і лейцин основні амінокислоти зерна. 3 дев'яти досліджених зразків пшениці, лише зерно сорту Кулундинка мали бездефіцитний амінокислотний скор (91-298\%), а в сорту Паннонікус вміст метіоніну був у дефіциті (49\%). Найкраще збалансований вміст амінокислот у зерні неспельтоподібних ліній, отриманих шляхом гібридизації Triticum aestivum L./Triticum spelta L., a саме P 7 i LPP 1314. У зерні цих ліній є бездефіцитний амінокислотний скор, крім метіоніну (64-74 \%), найкраще забезпечує добову потребу людського організму. Зерно має високий показник комплексного оцінювання та коефіцієнт ефективності метаболізму для незамінних амінокислот.

Ключові слова: амінокислоти, зерно, пшениця м'яка, сорт.

\section{Характеристика аминокислотного состава зерна} новыхсортов и линий пшеницы

Г. Н. Господаренко, В. П. Карпенко, В. В. Любич, В. В. Новиков

Уманский национальный университет садоводства, ул. Институтская, 1, г. Умань, Черкасская обл., 20300, Украина e-mail: Hospodarenko@gmail.com, v-biology@ukr.net,LyubichV@gmail.com, 1990vovanovikov1990@gmail.com

Цель. Определить формирование связанных аминокислот в зерне новых сортов пшеницы мягкой и его биологическую ценность. Методы. Полевой, физикохимический, расчетный анализ. Результаты. Проанализированы различия аминокислотного состава новых 


\section{HOSPODARENKO et al.}

сортов и линий пшеницы. Установлено, что высокое содержание эссенциальных аминокислот был в зерне сорта Кулундинка $(5,18 \%)$ или более в 2,3 раза по сравнению со стандартом (2,99 \%). В зерне линий пшеницы мягкой, полученных гибридизацией Triticum aestivum L./Triticum spelta L., их содержание в 1,4-1,5 раза больше по сравнению с контролем. Зерно пшеницы мягкой сорта Кулундинка имеет самую высокую биологическую ценность, так как скор эссенциальных аминокислот бездефицитный, а остальные сорта имеют дефицит 2-5 аминокислот. В зерне линий пшеницы мягкой только метионин был в дефиците (аминокислотный скор 64-74 \%). Выводы. Содержание аминокислот в зерне пшеницы мягкой в значительной степени зависит от погодных условий, селекционногенетического происхождения сорта и линии. Было установлено, что глутаминовая кислота, пролин и лейцин основные аминокислоты. Из девяти образцов исследованных образцов пшеницы мягкой только зерно сорта Кулундинка имело бездефицитный показатель аминокислот (91-298\%), а в сорте Панноникус метионин был дефицитный (49 \%). Наилучше сбалансированное содержание аминокислот в зерне неспельтоидных линий, полученных гибридизацией Triticum aestivum L./ Triticum spelta L., а именно P 7 и LPP 1314. Зерно этих линий имеет бездефицитный аминокислотный скор, кроме метионина (64-74\%), наибольше удовлетворяет суточную потребность человеческого организма ими. Зерно имеет высокий показатель комплексной оценки и коэффициента эффективности метаболизации для незаменимых аминокислот.

Ключевые слова: аминокислоты, зерно, пшеница мягкая, сорт.

\section{REFERENCES}

1. Kiseleva MI, Kolomiets TM, Pakholkova EV, Zhemchuzhina NS, Lubich $V V$. The differentiation of winter wheat (Triticum aestivum L.) cultivars for resistance to the most harmful fungal pathogens. Agricultural Biology. 2016;3:299-309. doi: 10.15389/agrobiology.2016.3.299rus.

2. Vieira EF, Soares $C$, Machado $S$, Correia M, Ramalhosa MJ, Oliva-Teles MT et al. Seaweeds from the Portuguese coast as a source of proteinaceous material: Total and free amino acid composition profile. Food Chem. 2018; 269:264-75. doi: 10.1016/j.foodchem.2018.06.145.

3. Jiang Xiao-ling, Tian Ji-chun, Hao Zhi, Zhang Weidon. Protein Content and Amino Acid Composition in Grains of Wheat-Related Species. Agricultural Sciences in China. 2008; 7(3): 272-279. doi.org/10.1016/S16712927(08)60066-8.

4. Fedorova $D V$. New salty wafer products "Krekisy fish", made using fish-plant semi-finished products. Path of Science - Electronic Scientific Journal. 2016;2(4):3.6-3.17.
5. Su WH, Sun $D W$. Facilitated wavelength selection and model development for rapid determination of the purity of organic spelt (Triticum spelta L.) flour using spectral imaging. Talanta. 2016;155:347-57. doi: 10.1016/j. talanta.2016.04.041

6. Subramanyam S, Shreve JT, Nemacheck JA, Johnson AJ, Schemerhorn B, Shukle, RH, Williams CE. Modulation of non-essential amino acid biosynthetic pathways in virulent Hessian fly larvae (Mayetiola destructor), feeding on susceptible host wheat (Triticum aestivum). J Insect Physiol. 2018;105:54-63. doi: 10.1016/j.jinsphys. 2018.01.001.

7. Graciela Caire-Juvera, Francisco A. Vazquez-Ortiz, Maria I. Grijalva-Haro. Amino acid composition, score and in vitro protein digestibility of foods commonly consumed in Northwest Mexico. Nutr Hosp. 2013;28(2): 365-71. doi:10.3305/nh.2013.28.2.6219.

8. Grasgruber P, Cacek J, Hřebrčkovo S. The Amino Acid Score and Physical Growth: Implications for the Assessment of Protein Quality. International Scholarly and Scientific Research \& Innovation. 2013; 7(12): 94953.

9. Tomic J, Torbica A, Popovic L, Hristov N, Nikolovski B. Wheat bread making properties in dependence on wheat enzymes status and climate conditions. Food Chem. 2016; 199:565-72. doi: 10.1016/j.foodchem.2015.12.031.

10. Aradottir GI, Martin JL, Clark SJ, Pickett JA, Smart $L E$. Searching for wheat resistance to aphids and wheat bulb fly in the historical Watkins and Gediflux wheat collections. Ann Appl Biol. 2017;170:179-88. doi: 10. 1111/aab.12326.

11. Litun P, Kirichenko V, Petrenkova V, Kolomatska V. Systematic analysis in field crop selection. Kharkiv, Margha LTD. 2009;351 p.

12. Tsarenko O, Zlobin Y, Sklyar V, Panchenko S. Computer methods in agriculture and biology. Sumy, LLC (ElitaStar). 2000;200 p.

13. Escarnot E. Comparative study of the content and profiles of macronutrients in spelt and wheat, a review. Biotechnology, Agronomy, Society and Environment. 2012;16(2): 243-56.

14. Gallardo C, Dadalt JC, Trindade Neto MA. Nitrogen retention, energy, and amino acid digestibility of wheat bran, without or with multicarbohydrase and phytase supplementation, fed to broiler chickens. J Anim Sci. 2018;96(6): 2371-9. doi: 10.1093/jas/sky062.

15. Paucean A, Moldovan OP, Muresan V, Socaci SA, Dulf FV, Alexa E, Man SM, Muresan AE, Muste S. Folic acid, minerals, amino-acids, fatty acids and volatile compounds of green and red lentils. Folic acid content optimization in wheat-lentils composite flours. Chem Cent J. 2018;12(1):88-105. doi: 10.1186/s13065-0180456-8. 